Volume I Tahun 2021

November 2021
E-ISSN: 2808-5361

http://e-journal.fkmumj.ac.id/
Proceeding The First

Muhammadiyah

Internasional- Public Health

and Medicine Conference

\title{
THE ROLE OF THE COMMUNITY IN COMBATING THE COVID-19 PANDEMIC IN INDONESIA
}

\author{
${ }^{1}$ Djufri Nurachman, ${ }^{2}$ Dewi Purnamawati \\ ${ }^{1}$ Karya Bhakti Pratiwi Hospital \\ Raya Dramaga KM 7.3 Street, Bogor, Jawa Barat \\ ${ }^{2}$ Faculty of Public Health, Muhammadiyah University of Jakarta \\ K.H. Ahmad Dahlan Street, Cireundeu, Ciputat, Tangerang Selatan, Banten 15419 \\ E-mail: drdj0712@gmail.com
}

\begin{abstract}
Corona Virus Diseases 19 (Covid-19) has become a global threat. The role of the community is very much needed to break the chain of transmission of Covid-19. This study aims to determine the role of the Indonesian people in overcoming the Covid-19 pandemic in general, health, education, and the economy. Research method: using SLR. Data is collected from Scopus and indexed journals through a science direct and Garuda-based data system. Data were analyzed using content analysis techniques. Research Results: Indonesian people have implemented health protocols in the form of using masks outside the home, complying with PSBB policies, washing hands regularly. In the health sector, supporting health workers by helping to raise funds for PPE, conducting regional quarantine. In supporting education policies during the Covid-19 period, the context of which is the government, teachers, and parents, have been with all their might and dedication to provide facilities for students in the form of data packages, relaxation of curriculum policies, elimination of National Examinations, the effectiveness of teaching and learning activities in Indonesia. during the pandemic. To respond to the economic downturn itself, the community supports the return of the Indonesian economy, such as opening small businesses online, supporting policies for providing assistance and relaxing MSME loans by submitting small businesses, supporting government policies on tax relaxation. while still paying taxes. Conclusion: In general, the Indonesian people have been quite disciplined in trying to prevent the spread of COVID-19, both in the fields of health, education, and the economy.
\end{abstract}

Keywords: The Covid-19 Outbreak, The Role of the Community, Covid Handling 
Volume I Tahun 2021

November 2021
E-ISSN: 2808-5361

http://e-journal.fkmumj.ac.id/

\author{
Proceeding The First \\ Muhammadiyah \\ Internasional-Public Health \\ and Medicine Conference
}

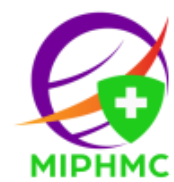

\section{INTRODUCTION}

The emergence of the Corona Virus globally was detected from the beginning of December 2019(Hope et al., 2020). The emergence of this disease is characterized by a disturbance in the human respiratory system(J.-M. Qu et al., 2021b; J. Qu \& Wang, 2021). This virus first attacked Wuhan City, Hubei Province, China before being recognized internationally by the World Health Organization (WHO) on January 30, 2020. (Hope et al., 2020). As of February 14, 2020, on International Valentine's Day, 49,053 laboratories in the world confirmed that 1,381 deaths had occurred worldwide. (Hope et al., 2020). With the emergence of diseases that take lives worldwide, Covid-19 (Corona Virus Disease) is classified as one of the biggest threats to the world community today. (Meng et al., 2020; J.-M. Qu et al., 2021d).

Various kinds of research from health experts, doctors, and other health workers related to the spread of this virus never subsided. The latest thing that has been discovered in the development of a type of vaccine for this virus is believed to prevent the development of the Covid-19 virus and is also believed to be a means of controlling its spread and reducing deaths. (Rawat et al., 2021). The main thing that these countries can now do before they can distribute vaccines in their entirety to their people is to run an incubation period or self-quarantine for a minimum of 7-14 days and implement health protocols regularly. (J.-M. Qu et al., 2021a, 2021c). In addition, before vaccines are proven to be effective in saving humanity from this dangerous virus, countries around the world will certainly continue to experience changes that harm the sustainability of people's lives.

The literature has confirmed that the Corona Virus has a serious impact on various sectors in the world, especially in the health, education, and economic sectors.(Chaturvedi et al., 2021; Shrestha et al., 2020; Zhao, 2020). From the health sector, there are more than 5.2 million new positive cases and it is also recorded that the number of deaths in the world has reached tens of thousands of people with 10 countries being the biggest contributors, namely, America, India, Brazil, France, Russia, Turkey, England, Italy, Spain, and Germany(Septiani, 2021). Indonesia did not escape the award for the second-highest country in Southeast Asia in 2020 with a total of 315,714 cases(Hira \& Amelia, 2020). In terms of education, face-toface learning had to be replaced with online learning (in the network) which made teachers, students, and also parents stuck. Not to forget, the Corona Virus has also made a negative contribution to economic development around the world.

If analyzed again, the spread of Covid-19 is not indiscriminate. Developing and developed countries around the world are noted to be affected by its spread. Indonesia, which is predicted to be on the way to a status transition from a developing country to a developed country(Bardan, 2021; BBC News Indonesia, 2021) also not absent from the impact caused by this pandemic. 
Volume I Tahun 2021

November 2021
E-ISSN: 2808-5361

http://e-journal.fkmumj.ac.id/
Proceeding The First

Muhammadiyah

Internasional- Public Health

and Medicine Conference

Based on the background described previously, researchers are very interested in discussing the role of the Indonesian people in dealing with the Covid-19 pandemic. The things that will be discussed in this paper are as follows, (1) the role of the Indonesian people in dealing with the Covid-19 pandemic in general; (2) the role of the Indonesian people in combating the impact of Covid-19 on the health sector; (3) the role of the Indonesian people in combating the impact of Covid-19 on the education sector; and (4) the role of the Indonesian people in combating the impact of Covid-19 on the economic sector.

\section{METHODS}

This research method using SLR or systematic literature review is a literature review method that identifies, assesses, and interprets all findings on a research topic, to answer research questions that have been determined previously. SLR is carried out systematically by following stages and protocols that allow the literature review process to avoid bias and subjective understanding of the researchers. Data was collected from Scopus and Sinta indexed journals through data-based science direct and garuda systems. The data is searched using the keyword "the role of society during the covid 19 pandemics with 2020 and 2021 limits. The data is analyzed using content analysis techniques.

\section{RESULTS AND DISCUSSIONS}

This section will describe four points that will become the topic of discussion, namely, 1) The role of the Indonesian people in dealing with the Covid-19 pandemic in general; 2) Role in the health sector; 3) Role in the education sector; and (4) The role in the economic sector.

\section{The Role of the Indonesian Society in Overcoming the Covid-19 Pandemic in General}

Since the beginning of 2020, where the Corona Virus has been officially recognized as a world epidemic or pandemic by the WHO, the Indonesian government has been aggressively making several policies. This is related to the government's active efforts to provide alternative preventive efforts in dealing with the outbreak. The Indonesian government has also tried to implement policy transparency(Muis, 2020).

But actually, it is the community that is at the forefront of breaking the virus chain with selfdiscipline as the main key (Bakti \& Adisasmito, 2020). This confirms that the role of the community in general in supporting and carrying out the policies of the Indonesian government in dealing with the Covid19 pandemic is needed (Shah, 2019). Some of the policies that are still being implemented are health protocols, including the use of masks when doing activities outside the home and maintaining hygiene which includes washing hands properly and properly and being disciplined in maintaining health patterns independently. 
Volume I Tahun 2021

November 2021
E-ISSN: $2808-5361$

http://e-journal.fkmumj.ac.id/
Proceeding The First

Muhammadiyah

Internasional- Public Health

and Medicine Conference

Indonesia has also been recorded to carry out several Large-Scale Social Restrictions (PSBB) policies. The literature has confirmed that policies in the form of a large-scale lockdown or isolation have proven effective in breaking the chain of the spread of the Corona Virus(Bakti \& Adisasmito, 2020). Even though Indonesia does not implement a full lockdown policy, namely the semi-lockdown called PSBB, several studies have also confirmed that the implementation of this PSBB has proven to be effective in breaking the virus chain (Askar et al., 2020; Ristyawati, 2020).

The Role of the Indonesian Society in Combating the Impact of Covid-19 in the Health Sector

Confirmed by the literature, as of 2020, the world community has been competing in contributing individually and in groups to rebuild health in their respective countries. (Sitohang et al., 2020). This was also confirmed by the WHO as well that the world community who is active in contributing energy, thoughts, and finances when helping to overcome Covid-19 is very much needed and has an important role in itself. (Sitohang et al., 2020).

The role of the community in general in breaking the chain of virus spread is also seen in Indonesia. The roles of the Indonesian people in breaking the chain of the spread of the Corona Virus are as follows.

According to Sitohang et al., (2020), the Indonesian people are actively conducting regional quarantine and closing access portals to their respective residential areas; implementing health protocols in the form of using masks outside the home, washing hands, maintaining distance, disinfection, and providing health certificates for informal workers; provision of buildings for self-isolation; manufacture and distribution of masks, hand sanitizers, and PPE for health workers (nakes); fundraising for PPE health workers; door-to-door socialization about the importance of personal health and hygiene; and the hashtag movement at home (\#at home) on various social media channels.

Full support for the Healthcare Workers Security (HWS) program from the community to fight for the rights of Indonesian health workers who incidentally are one of the frontline troops fighting for health during the pandemic(Hira \& Amelia, 2020). This HWS focuses on two important things related to the rights of health workers, namely legal protection to provide a sense of security for the health workers themselves in carrying out their duties, and this protection contains two legal protection measures, namely repressive and preventive. The second is the rights of health workers related to other rights outside the imperative rights of the government.

Officially, in 2020, the Indonesian government has announced four major strategies that will then be implemented in the context of dealing with Covid-19 - which is also to strengthen the physical distancing program. The four strategies are as follows, the mandatory use of masks outside the home, tracing of positive cases using rapid tests, education on the preparation of self-isolation for positive cases resulting 
Volume I Tahun 2021

November 2021
E-ISSN: $2808-5361$

http://e-journal.fkmumj.ac.id/
Proceeding The First

Muhammadiyah

Internasional- Public Health and Medicine Conference

from tracing, and isolation programs for hospitals and emergency hospitals such as Wisma Atlet and Galang Island. (covid19.go.id, 2020).

It was recorded that in the same year, namely 2020, the role of all community groups starting from the community, RT, RW, and Village has been recorded to effectively support community programs. This is evidenced by data showing the number of laboratories that can perform PCR examinations as many as 43 , specimens tested as many as 59,935, cases examined by 48,647 people. The results shown are the addition of cases to a total of 960 people, and a total of 647 patients died.

It was also noted that the government was still monitoring people suspected of having direct contact with positive COVID-19 patients. This early resulted in ODP data of 195,948 in 2020. Most of these cases have been monitored and are in good health. The number of PDP is 18,283 people in 2020.

This proves that there is a positive response and cooperation from the community towards government programs as listed above. Other evidence that shows a positive response and cooperation from the Indonesian people towards government programs in the context of dealing with Covid-19 can be seen from the results of a survey participated by 10,199 people and reported by Kompas.com in 2020, which are as follows.

1. The government was not fast and effective in dealing with the spread of 42.8 percent.

2. The government has had enough in dealing with Covid-19 as much as 33.2 percent.

3. The government disappointed from the start (handling) to reach 16.4 percent

4. The government's attitude is proud of reaching 5.6 percent.

With the role of the community in contributing to the survey on government programs, the transparency of the reflection on government programs can also be seen, so that it can be improved together in its implementation in the future.

\section{The Role of the Indonesian Society in Combating the Impact of Covid-19 in the Education Sector}

Learning activities in schools are also one of the things most affected by the Covid-19 pandemic. Conventional teaching and learning activities that we have known for decades have suddenly turned into an online teaching and learning system. Until now, public schools in Indonesia are still implementing an online teaching and learning system. However, in contrast to public schools, various private and international schools have begun to gradually implement hybrid learning or a combination of offline and online. Various learning channels are used to keep learning activities running, such as WhatsApp, Zoom, and Google Classroom, etc(Adawiyah, 2020).

Various kinds of education policies in Indonesia have been implemented to adapt to the pandemic which in its prevention must minimize physical contact between humans. In addition to the distance 
Volume I Tahun 2021

November 2021
E-ISSN: $2808-5361$

http://e-journal.fkmumj.ac.id/
Proceeding The First

Muhammadiyah

Internasional- Public Health

and Medicine Conference

learning policy, the abolition of the National Examination, and internet assistance for distance learning channels, curriculum relaxation has also been implemented in Indonesia. It is hoped that teachers will not focus too much on achieving the learning target of one semester, but rather on emphasizing character and morals(Love, 2020). The Ministry of Education and Culture of Indonesia also initiated the Learning From Home Program (BDR). This BDR was carried out on the television channel of the Republic of Indonesia (TVRI). This is done to facilitate Indonesian students who have internet limitations.

With this distance learning policy, support from the community in general, especially from the teachers and parents of students can be seen. The teachers do their best to facilitate students with learning materials and distance learning activities that are as simple and effective as possible. From the perspective of parents, who were a little overwhelmed at first, now they have started to open up to this distance learning program and support and provide the maximum possible facilities for their children.

The Role of the Indonesian Society in Combating the Impact of Covid-19 in the Economic Sector

The world economy is in recession due to the impact of Covid-19(Wuryandani, 2020). It is undeniable that the Indonesian economy has also been affected by this pandemic. The impact is no joke. Tourism and trade are the biggest economic sectors affected by the spread of this virus(Budiyanti, 2020; Tetri, 2020).

There are several things that the Indonesian people do for the sake of the survival of the country's economy. As for the things that are being done, such as opening small businesses online, supporting the policy of providing assistance and relaxation of MSME loans by proposing small businesses, supporting government policies on tax relaxation by continuing to pay taxes, and controlling yourself by being frugal and not panic buying. which will prevent the emergence of new problems, namely the decline in food supply(Anggreani, 2020).

\section{CONCLUSION AND SUGGESTIONS}

Indonesia is one of the countries affected by the emergence of the Corona Virus globally which was detected in early December 2019 (Hope et al., 2020). The Coronavirus that does not subside has a serious impact on various sectors in the world, including Indonesia, especially in the health, education, and economic sectors.(Chaturvedi et al., 2021; Shrestha et al., 2020; Zhao, 2020).

This study describes four points that are the topic of discussion, namely, (1) the role of the Indonesian people in dealing with the Covid-19 pandemic in general; (2) the role of the Indonesian people in combating the impact of Covid-19 on the health sector; (3) the role of the Indonesian people in combating 
Volume I Tahun 2021

November 2021
E-ISSN: $2808-5361$

http://e-journal.fkmumj.ac.id/
Proceeding The First

Muhammadiyah

Internasional- Public Health

and Medicine Conference

the impact of Covid-19 on the education sector; and (4) the role of the Indonesian people in combating the impact of Covid-19 on the economic sector.

In general, the Indonesian people have implemented health protocols in the form of using masks outside the home, complying with PSBB policies, washing hands regularly, and maintaining personal hygiene and health. In the health sector, the Indonesian people have also supported health workers by helping to raise funds for PPE, using hand sanitizers, masks, conducting regional quarantines, and especially supporting HWS. In supporting education policies during Covid-19, the Indonesian people, in which the context here is the government, teachers, and parents, have been with all their might and dedication to provide facilities for students. Assistance in the form of data packages, curriculum relaxation policies, elimination of the National Examination, the effectiveness of teaching and learning activities, and full support at home is a separate contribution to the running of teaching and learning activities in Indonesia during the pandemic. To respond to the economic downturn itself, the community has consciously carried out various positive activities to support the return of the Indonesian economy, such as, opening small businesses online, supporting policies for providing assistance and relaxation of MSME loans by proposing their small businesses, supporting government policies on relaxation taxes by continuing to pay taxes and controlling yourself by not doing panic buying which will prevent new problems from occurring, namely the decline in food supply(Anggreani, 2020).

\section{REFERENCES}

Adawiyah, S. El. (2020). Our Opinion for COVID-19 Series I-1 (Issue July). Independent Intellectual Persons.

Anggreani, R. (2020). 7 Economic Policies to Face the Covid-19 Pandemic Sindonews.Com.

Annajih; Fakhriyani; Sa'idah. (2021). Indigenous Counseling: Study on Compliance. Edu Consilium: Journal of Islamic Education Counseling, 2(1), 1-11.

Askar, MW, Permana, MY, \& Rakhmat, MZ (2020). Research reveals that PSBB is effective in preventing the spread of the virus, the government should not rush to implement the 'new normal.' The Conversation.

Bakti, W., \& Adisasmito, B. (2020). The Impact of Public Attitudes on Prevention of Coronavirus Disease19 Transmission: Literature Review. IAKMI Indonesian Journal of Public Health, 1(3).

Bardan, AB (2021). Jokowi said that 2021 will be the momentum for Indonesia to become a developed country. Nasional.Kontan. Co.Id.

BBC News Indonesia. (2021). Indonesia is called a developed country by the US: What is the impact on 
Volume I Tahun 2021

November 2021
E-ISSN: $2808-5361$

http://e-journal.fkmumj.ac.id/
Proceeding The First

Muhammadiyah

Internasional- Public Health

and Medicine Conference

the relief of import duties on imported goods? BBC News Indonesia.

Budiyanti, E. (2020). The Impact of the Corona Virus on the Trade Sector And. 2015.

Chaturvedi, K., Vishwakarma, DK, \& Singh, N. (2021). COVID-19 and its impact on education, social life and mental health of students: A survey. Children and Youth Services Review, 121, 105866. https://doi.org/https://doi.org/10.1016/j.childyouth.2020.105866

covid19.go.id. (2020). Four Government Strategies to Overcome COVID-19. Covid19.Go.Id.

Harapan, H., Itoh, N., Yufika, A., Winardi, W., Keam, S., Te, H., Megawati, D., Hayati, Z., Wagner, AL, \& Mudatsir, M. ( 2020). Coronavirus disease 2019 (COVID-19): A literature review. Journal of Infection and Public Health, 13(5), 667-673. https://doi.org/10.1016/j.jiph.2020.03.019

Hira, H., \& Amelia, T. (2020). HEALTHCARE WORKERS SECURITY: Guarantees, Regulations, and Sanctions. Equator Law Review, 1(4), 109-129.

Love, AP (2020). Covid-19, these are a series of changes in education policy in Indonesia. Kompas.Com.

Meng, X., Shi, L., Yao, L., Zhang, Y., \& Cui, L. (2020). Change in outdoor walking behavior during the coronavirus disease pandemic in Japan: a longitudinal study. Colloids and Surfaces A: Physicochemical and Engineering Aspects, Iii, 124658. https://doi.org/10.1016/j.jiec.2021.03.022

Muis, ARC (2020). Public Policy Transparency as a National Strategy in Overcoming the Covid-19 Pandemic SALAM: Social and Cultural Journal of Syar-I, 7(5). https://doi.org/10.15408/sjsbs.v7i5.15317

Qu, J.-M., Cao, B., \& Chen, R.-C. (2021a). Clinical features of COVID-19. In Covid-19 (Issue 5, pp. 1339). https://doi.org/10.1016/b978-0-12-824003-8.00003-6

Qu, J.-M., Cao, B., \& Chen, R.-C. (2021b). Diagnosis of COVID-19. In Covid-19 (pp. 41-54). https://doi.org/10.1016/b978-0-12-824003-8.00004-8

Qu, J.-M., Cao, B., \& Chen, R.-C. (2021c). Prevention and disease control of COVID-19. In Covid-19 (pp. 75-88). https://doi.org/10.1016/b978-0-12-824003-8.00006-1

Qu, J.-M., Cao, B., \& Chen, R.-C. (2021d). Respiratory viruses and COVID-19. In Covid-19 (pp. 1-6). https://doi.org/10.1016/b978-0-12-824003-8.00001-2

Qu, J., \& Wang, C. (2021). Prologue. In Covid-19 (pp. ix-x). https://doi.org/10.1016/b978-0-12-8240038.10000-2

Rawat, K., Kumari, P., \& Saha, L. (2021). COVID-19 vaccine: A recent update in the vaccines pipeline, their design, and development strategies. European Journal of Pharmacology, 892(September 2020), 173751. https://doi.org/10.1016/j.ejphar.2020.173751

Ristyawati, A. (2020). The Effectiveness of Large-Scale Social Restrictions Policy During the 2019 Corona 
Virus Pandemic by the Government by the Mandate of the 1945 Constitution of the Republic of Indonesia. Administrative Law and Governance Journal, 3(2), 240-249. https://doi.org/10.14710/alj.v3i2.240-249

Septiani, A. (2021). World Weekly Corona Sets a Record, These 10 Countries Become the Most Contributors. DetikHealth.Com.

Shrestha, N., Shad, MY, Ulvi, O., Khan, MH, Karamehic-Muratovic, A., Nguyen, USDT, Baghbanzadeh, M., Wardrup, R., Aghamohammadi, N., Cervantes, D., Nahiduzzaman, KM, Zaki, RA, \& Haque, U. (2020). The impact of COVID-19 on globalization. One Health, 11, 100180. https://doi.org/10.1016/j.onehlt.2020.100180

Sitohang, MY, Rahadian, AS, \& Prasetyoputra, P. (2020). Indonesian Community Initiative In The Early Phase of The COVID-19 Pandemic: A Health Development Strategy. Indonesian Population Journal, 2902(April).

Shah, M. (2019). The Importance of Attitudes and the Role of the Community in the Time of the COVID19 Pandemic.

Tetri. (2020). The Government's Role in Overcoming the Covid-19 Pandemic Faculty of Economics and Business, Eleven Maret University.

Wuryandani, D. (2020). The Impact of the COVID-19 Pandemic on Indonesia's 2020 Economic Growth and Solutions. Brief Information on Economics and Public Policy Research Center Expertise Board of the Republic of Indonesia, 12(15), 19-24.

Zhao, B. (2020). COVID-19 pandemic, health risks, and economic consequences: Evidence from China. China Economic Review, 64, 101561. https://doi.org/https://doi.org/10.1016/j.chieco.2020.101561 